\title{
重質油のキャラクタリゼーションとその応用 一緒論一
}

石油学会精製部会重質油分科会

石油精製工程でできる重質残油は量的に非常に多い上に，含 有される硫黄, 窒素などが環境污染を起こす。また OPEC 諸 国の原油值上げ政策で石油製品は急激な值上がりを余儀なくさ れて来ている。更に今後輸入される原油は徐々に重質化して行 く見通しであり, 石油依存率の低下に効果的なオイルサンドビ チューメン, 天然アスファルト, 石炭液化油などはいつうれも極 めて重質である。

このような事情から高価格の炭化水素資源の有効利用と重質 炭化水素のクリーンな軽質分への転化技術の開発が重要な研究 課題となって来た。これを化学反応の面から見ると低分子化反 応と高分子化反応に分けることができる。低分子化反応には低 温熱分解, 接触分解, 水素化分解, 高温熱分解によるオレフィ ンの製造，ガス化などがあり，高分子化反応には熱縮重合によ る粘結材ピッチの製造, 炭化反応による各種炭素材の製造など がある。

これらの諸反応を利用した新しい技術開発も活発に行われて いる。ビスブレーキングなどの低温熱分解は安価な軽質化法ま たは接触分解などの前処理技術として近年見直されて来てい る。残油の接触分解, 水素化分解は昭和 54 年 6 月に発足した重 質油対策技術研究組合でも中間留分製造技術として開発課題に 取り上げられている。残油の高温熱分解によるオレフィンの製 造研究は残油処理量 $120 \mathrm{t} /$ day の実証プラントが昭和 54 年 10 月に重質油化学原料化技術研究組合によって建設を完了した。 また重質油のガス化技術については部分酸化法のほかに水蒸気 改質法も著しい進歩を遂げ， $\mathrm{C}_{1}$ の化学工業の新しい幕あけを 待っている。一方高分子化反応による粘結材ピッチ, ニードル コークス, 活性炭素材などの製造はすでに工業プラントがか動 している状況にある。

ところがこれら処理技術の基本となる重質油のキャラクタリ ゼーションの手法については従来極く少数の研究者の手に委㸚 られているに過ぎなかったが，昭和 49 年 10 月東北大学で催さ れた日本化学会秋季年会のブラックケミストリ一特別討論会に おいて重質油の化学と有効利用技術の開発の重要性について広 く共通の認識が持たれ，これを契機として有志による研究会が 発足し, 従来行われていた原油, 軽質留分, 潤滑油, タール, ピッチならびに石炭類のキャラクタリゼーションの研究を参考 にして, 重質油を性格づる手法の研究が開始された。そして 従来使われていたキャラクタリゼーションファクターの重質油 への拡張の可能性の検討, 各委員が持ち寄った重質油関する 研究データの検討などを行い, その成果を「重質油のキャラク タリゼーションとその研究手法」と題して本誌第 19 巻 11 号

* 昭和 55 年 1 月 29 日受理
に揭載した。

その後昭和 52 年 5 月に石油学会の精製部会に新たに重質油 分科会を設置して研究を継続することとなった。分科会委員は 従来の研究会委員を中核とし, 当該分野に関係の深い大学, 研 究所, 企業の専門家によって構成されている。現在までの研究 成果としては重質油の平均的化学構造の推算法をほぼ確立し, かつ各種物性值を測定してキャラクタリゼーションの手法につ いて検討を加えた。更に, $500^{\circ} \mathrm{C}$ 以下の低温熱分解による縮重 合, 水蒸気改質によるガス化, 水素化脱硫の 3 反応を取り上げ て, 原料油, 生成油の平均的化学構造, 諸物性值との関係を解 明して一応の成果を得たので，その概要をここに公刊すること にした。これらの研究では多数の分析項目を多数の委員が分担 して測定することにしたばかりでなく, 研究成果を共通の広場 で議論できるように共通試料を使用したことが大きな特色であ る。

なお，本分科会活動の最終目標は重質油の各種反応を十分理 解するためキャラクタリゼーション因子の最適組合せによる反 応特性の評価方法を確立するにある。従ってなお数種の反応の 検討が必要であり, 試料油種も溶剂脱れき残さ, 各種ピッチ類, 石炭液化油など芳香族性の高いものについてもこの評価方法の 適性を確認寸る必要があると考えられる。

最後に本分科会の活動を可能としていただいた石油学会精製 部会, 委員の所属企業, 研究所の御支援, 御協力に対して厚く 御礼申し上げる次第である。

（功刀泰碩 記）

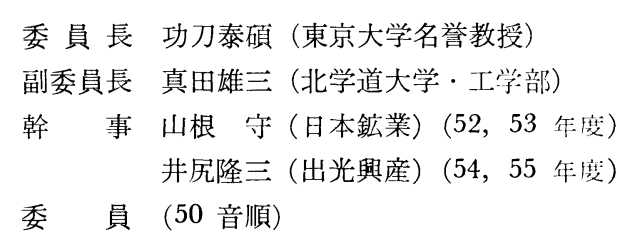

飯島博（三菱石油）

今村 敏英（富士興産）

上村 誠一（日本石油）

久村 幸正 (興要石油)

中島 正人 (三菱油化)

平戸 瑞穂（日立製作所）

藤元 薰 $\left(\begin{array}{c}\text { 東京大学 } \\ \text { 部 }\end{array}\right.$

三戸岡憑之（丸善石 油）

矢幡悌三郎（千代田化工）

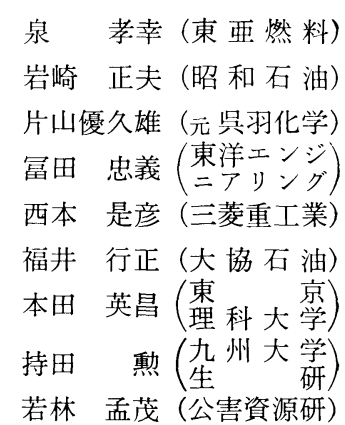

泉孝（東亚然料）

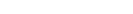
亘田 福井行正 (大協石油) 本田英昌 (東 理 科学) 若林子茷 (公害資源研) 